no less than 777 scientific workers, having completed the work of their fellowships, have entered the field of manufacture or teaching, and this forms not the least valuable contribution to the promotion of science and industry. In recent years, the Institute has greatly developed its work of a more purely scientific character or bearing on public health. Its investigations on smoke abatement, dental caries, and anti-pneumococcic serum are examples.

With a view to simplicity, beauty and inspiration, the new building was designed in the Greek style (Fig. 1) with a relatively low elevation, three storeys being below ground level. The building has a capacity of $\epsilon_{2} \frac{1}{2}$ million cutic feet. Its colonnades have a total of sixty-two columns, each shaft--a single block of stone-weighing approximately 60 tons, of which twelve are on the south frontage, sixteen on the east and west and eighteen on the north. At the corners are impressive piers. Models were found in the small temple of Nike Apteros on the Acropolis and in the temple at Sardis in Asia Minor. On three sides a flight of steps leads up to the building. The fifth to eighth floors are devoted entirely to laboratories, most of the space being occupied by the two types of laboratory adopted by the Institute as standard. Doors connecting the laboratories are of aluminium adorned with alchemical symbols.

In accepting in 1935 the Chemical Industry Medal of the Society of Chemical Industry, Dr. Weidlein, the director, said that his task at the Institute had been to assist in infusing science into technology, particularly the chemical industry. This task had two aspects - to convince manufacturing organizations of the functions of scientific research and research management in industry, and to encourage in the public a greater appreciation of the value of science. Thanks to the work of the industrial fellows, the Institute formed a strong link between the world of science and the industries. His concluding words were :

"What about the future? I believe that all of us at the Institute will have much greater encouragement and opportunities and that we shall be able to do many more useful things when we have the advantage of working in our new building with its splendid facilities for research in pure as well as applied science."

\title{
Kew's Contribution to Empire Botany
}

$\mathrm{V}^{1}$ ISITORS to the Royal Botanic Gardens, Kew, who usually see only the Gardens and Muscums, can have little idea of the great role that the Herbarium near the Main Gate has played in the botanical service of the Empire. Since the Herbarium was founded in 1852, members of the staff have, indepen. dently and collectively, and in association with other botanists, accomplished a vast arnount of floristic work. In order to show the extent of this to the numerous visitors, particularly from overseas, who will no doubt visit the Gardens during the Coronation period, a special exhibit has been arranged in No. 3 Museum. In a large glass case there has been placed a selection of works prepared either wholly by, or with the assistance of, the scientific staff of the Herbarium and Museums.

The general books shown include the classical work of G. Bentham and J. D. Hooker, the "Genera Plantarum", 1862-83, which has been and is still used by botanists in all parts of the world. Next in order is the "Index Kewensis", a work of universal importance compiled at the expense of Charles Darwin, under the direction of Sir J. D. Hooker, by the late B. Daydon Jackson, and continued by various members of the staff. This gives references to the original descriptions of all known species of flowering plants. Alongside is the great index of plant illustrations, the "Index Londinensis", edited by the late $O$. Stapf. Besides these are the "Hortus Kewensis" of W. Aiton, 1789, which records the species of plants in cultivation at Kew when still a 'royal garden'; the Botanical Magazine, the oldest of botanical periodicals, commenced in 1787, and still prepared at Kew, but since 1922 the property of the Royal Horticultural Society; the Kew Bulletin, which this year attains its golden jubilee, having been started in 1887; and Hooker's "Icones Plantarum", which last year attained its centenary, and which provides a medium for the illustration of plants of exceptional botanical interest.

The botany of the British Isles is represented by Hooker's "Students' Flora" (1870) and by the "British Flora" of G. Bentham (ed. 1, 1858).

The vegetation of much of China and Tibet is recorded in Forbes and Hemsley's "Index Floræ Sinensis" (1886-1905), Bentham's "Flora Hongkongensis" (1861), and Dunn and Tutcher's "Flora of Hong Kong" (1912).

India has been well catered for by the "Flora of British India", by J. D. Hooker and others (1872-97), and the "Flora of Bombay", by T. Cook (1901-08), the "Flora Simlensis", by Collett and Hemsley (1962), the "Flora of the Upper Gangetic Plain", by J. F. Duthie (1903-29); "Bengal Plants" by D. Prain (1903) ; and the "Flora of Madras", by J. S. Gamble, completed by C. E. C. Fischer (1915-36). The forestry of India is dealt with in "Indian Trees", by D. Brandis (1907), and the "Forest Flora of the Andaman Islands", by C. E. Parkinson (1923).

The "Flora of the Malay Peninsula" (1922-25) was a heary undertaking by ono botanist, H. N. Ridley ; and the "Enumeration of Siamese Plants" (1925- ) by the late W. G. Craib, is being continued.

The continent of Australia was early provided for by G. Bentham's fundamental work, the "Flora Australiensis" (1863-78), and J. D. Hooker's "F]ora of Tasmania" (1860), whilst the "New Zealand Flora" (1864-77), by J. D. Hooker, and the "Illustrations of the New Zealand Flora" (1914) by Cheeseman, assisted by W. B. Hemsley, have done much for the botany of that Dominion. J. D. Hooker's "Flora Antarctica" (1847) is a classical work for that region.

Africa has always taken a first place in the activities of the Kew Herbarium, and several works of considerable magnitude have been issued dealing with 
its flora. The "Flora of Tropical Africa" was begun by $\mathrm{D}$. Oliver in 1868 , and has been carried on by many botanists, part of the last family, the Gramineæ, commenced by O. Stapf and now being continued by C. E. Hubbard, only remaining to complete the huge task. The work of editing this great undertaking has been earried out by successive directors of Kew, Sir William T. Thiselton-Dyer, Sir David Prain, and Sir Arthur W. Hill, and part of the Euphorbiaceæ was contributed by Sir David Prain.

The "Flora of West Tropical Africa" (1927-36), by J. Hutchinson and $J$. M. Dalziel, is the first regional illustrated flora of the tropical part of the Continent; its "Economic Appendix" by J. M. Dalziel provides full information on the uses of West African plants. Smaller areas are dealt with in the "Flora of Liberia" (1906), by O. Stapf (in Johnston, "Liberia") ; "Trees and Shrubs of Sierra Leone" (1916) by C. E. Lane Poole ; "Gold Coast Trees and Shrubs" (1913), T. F. Chipp ; "Nigerian Trees" (1925), H. V. Lely ; "Flora of the Sudan" (1929), A. F. Broun and R. E. Massey, and its companion volume of illustrations by G. M. Crowfoot (1929); "Trees of Kenya Colony" (1926), E. Battiscombe ; "East African Grasses" (1926-27), by C. E. Hubbard.

The islands of Mauritius and the Seychelles wero provided for in J. G. Baker's "Flora" (1877), and latterly the "Seychelles Flora" has been cnumerated by V. S. Summerhayes.

The immense task of describing the rich and varied flora of what is now the Union of South Africa, begun by Harvey and Sonder in 1859, the "Flora Capensis", was continued by the Kew staff and others and completed in 1935. As in the case of the "Flora of Tropical Africa", the editorship has been in the hands of successive directors of Kew, Sir David Prain and Sir Arthur Hill also contributing largely to the taxonomic work. The "Flora of the Transvaal" (parts 1 and 2, 1926-32), by J. Burtt Davy, is the first of the regional descrirtive floras of South Africa. The descriptions for Mrs. E. F. Vallentin's "Illustrations of the Flowering Plants and Ferns of the Falkland Islands" were provided by Mrs. E. M. Cotton.

A. H. R. Grisebach's "Flora of the British West Indian Islands" was written in association with
Kow ; and the "Flora of Trinidad" (1928- ), by Williams and Cheesman, is also being prepared in close collaboration with Kew.

Among the general works by individual Kew botanists are the "Synopsis Filicum" (1868), of W. J. Hooker and J. G. Baker; the "Fern Allies" (1887), by J. G. Baker; "British Fungi" (1906), G. Massee ; "Diseases of Cultivated Plants and Trees" (1910), G. Massee; and J. Hutchinson's new phylogenetic classification in his "Families of Flowering Plants" (1926; 1935). "Plant Life in the Balkan Peninsula", W. B. Turrill (1929), is an intensive study of a special area.

Researches in sixtecnth century botany are represented by the "Herbal of Otto Brunfels", by T. A. Sprague (1928), and the "Herbal of Leonhart Fuchs", by T. A. Sprague and E. Nelmes (1931).

Applied botany is the subject of J. Smith's "Dictionary of Economic Plants" (I882), and his "Domestic Botany" (1871); G. Watt's monumental work, "A Dictionary of the Economic Products of India" (1889-93(6)), and jts abridgment, "The Commercial Products of India" (1908); the "Economic Produets of the Malay Peninsula" (1935), I. H. Burkill ; "Useful Plants of Nigeria" (1908-22), by J. H. Holland ; "Tropical Agriculture" (1929), revised by J. H. Holland; "Sorghum" (1936), J. D. Snowden ; "Crop Plants of the British Empire" (1936), by H. C. Sampson.

Among the more important books on horticulture and forestry are the "Dictionary of Gardening" (1884-88), by G. Nicholson; "The Trees of Great Britain and Ireland", H. J. Elwes and A. Henry 1905-13); "Trees and Shrubs Hardy in the British Isles" (1921), by W. J. Bean; "Rhododendrons" (1930), by $J$. Hutchinson (Kew), A. Rehder and $H$. Tagg (published by the Rhododendron Society); "Coniferæ" (1923), by W. Dallimore and A. Bruce Jackson, and the periodical, the Orchid Review (1893- ), founded and edited for many years by the late R. A. Rolfe. 'The history of the Gardens is dealt with in "The Royal Botanic Gardens, Kew" (1908), by W. J. Bean.

This list does not include, of course, the numerous smaller papers in scientific journals to which the Kew staff has so largely contributed.

\section{Calculating Machines in Scientific Computing}

$S^{c}$ IENTIFIC computing has been materially aided of late years by the development of calculating machines, a development in which scientific workers themselves have had a say. We may instance the use of the modern Brunsviga, with its split register and automatic transfer features, in statistical calculations; the application by Dr. L. J. Comrie of the Brunsviga twin 13z to the Hartmann formula for the reduction of prismatic spectrograms; the use of the Burroughs machine, and later the National Cash Register machine, in the Nautical Almanac Office for finite differencing and integration; the demonstration recently given at Cambridge of the application of the Hollerith rolling-total tabulator for the same purpose, and for general statistical calculations; the machine invented by Mr. R. R. Mallock at Cambridge for solving simultaneous equations; and the Bush machine developed at the Massachusetts Institute of Technology for the numerical solution of differential equations, and since installed by Prof. D. R. Hartree at Manchester.

For some years, the Mathematical Tables Committee of the British Association has conceritrated on the production of new tables by means of sub. tabulation on its "National" machine, a process which has revolutionized the art of table-making; the incidental advantage of having clean type copy produced by the machine for the printer has largely eliminated copying and setting errors. Checking by means of mechanical differencing of tables is equally 